\title{
ASSESSMENT OF THE PHYSIOLOGICAL POTENTIAL OF BELL PEPPER SEEDS AND RELATIONSHIP WITH SEEDLING EMERGENCE ${ }^{1}$
}

\author{
BRUNA GAGLIARDI², JÚLIO MARCOS FILHO³
}

\begin{abstract}
The objective in this study was to verify the efficiency of different procedures for evaluating the physiological potential of bell pepper seed and identify its relationship with germination at different temperatures and with seedling emergence. Five seed lots each of the Reinger and Sentinel hybrids were used. Seed physiological potential was evaluated by germination, saturated salt accelerated aging $\left(48 \mathrm{~h} / 41{ }^{\circ} \mathrm{C}\right.$ ), seedling emergence (percentage and speed), and tetrazolium tests (preconditioning at $45^{\circ} \mathrm{C} / 3 \mathrm{~h}$ and seed staining at $45{ }^{\circ} \mathrm{C} / 2 \mathrm{~h}$ ). Germination (percentage and speed) on a thermogradient table at $15^{\circ} \mathrm{C}, 18{ }^{\circ} \mathrm{C}, 21{ }^{\circ} \mathrm{C}, 25^{\circ} \mathrm{C}$ and $30^{\circ} \mathrm{C}$ was also evaluated the saturated salt accelerated aging and tetrazolium tests are suitable for access the physiological potential of bell pepper seeds. It was also confirmed that vigorous seed lots perform better when exposed to different temperatures during germination.
\end{abstract}

Index terms: Capsicum annuum, seed analysis, germination, vigor, temperature.

\section{POTENCIAL FISIOLÓGICO DE SEMENTES DE PIMENTÃO E RELAÇÕES COM A EMERGÊNCIA DE PLÂNTULAS}

\begin{abstract}
RESUMO - O presente trabalho, teve como objetivos verificar a eficiência de procedimentos para avaliação do potencial fisiológico de sementes de pimentão e identificar suas relações com a germinação sob diferentes temperaturas e com a emergência de plântulas. Utilizaram-se cinco lotes de sementes dos híbridos Reinger e Sentinel. A avaliação do potencial fisiológico foi efetuada mediante a condução de testes de germinação, envelhecimento acelerado com solução saturada de $\mathrm{NaCl}\left(48 \mathrm{~h} / 41^{\circ} \mathrm{C}\right)$, emergência de plântulas (porcentagem e velocidade), tetrazólio (précondicionamento a $45^{\circ} \mathrm{C}$ durante $3 \mathrm{~h}$ e coloração a $45^{\circ} \mathrm{C}$ durante $2 \mathrm{~h}$ ) e germinação (porcentagem e velocidade) em mesa termogradiente, a $15{ }^{\circ} \mathrm{C}, 18^{\circ} \mathrm{C}, 21{ }^{\circ} \mathrm{C}, 25^{\circ} \mathrm{C}$ e $30^{\circ} \mathrm{C}$. Concluiu-se que os testes de envelhecimento acelerado com solução saturada de $\mathrm{NaCl}$ e de de tetrazólio são adequados para a avaliação do potencial fisiológico de sementes de pimentão e que lotes mais vigorosos apresentam desempenho consistente sob variações relativamente amplas da temperatura durante a germinação.
\end{abstract}

Termos para indexação: Capsicum annuum, análise de sementes, germinação, vigor, temperatura.

\footnotetext{
${ }^{1}$ Submitted on 15/04/2010. Accepted for publication on 26/08/2010. Part of first author's Master's Dissertation presented at USP/ESALQ.

${ }^{2}$ Eng. Agr., M.S., USP/ESALQ, Department of Crop Science, Caixa Postal 9, 13418-900. Piracicaba, SP. CNPq scholarship; e-mail:
}

brugagliardi@gmail.com.

${ }^{3}$ Eng. Agr., Dr.; Professor, USP/ESALQ, Department of Crop Science. CNPq scholarship. e-mail: jmarcos@esalq.usp.br. 


\section{INTRODUCTION}

The standard germination test conducted underoptimal environmental conditions in the laboratory, generally overestimates the physiological potential of seed lots. Consequently, a consistent evaluation of physiological potential should include both seed germination and vigor. Determination of vigor, which depends on the interaction of various components, usually identifies aspects of seed performance during storage or in the field that were not detected by the germination test. For this reason, it is important to perform more than one vigor test (physiological, biochemical or resistance to stress), to generate more complete data for estimating the potential performance of seeds under different environmental conditions (Hampton and Coolbear, 1990).

Seed Vigor testing is an important component of quality control programs. The evaluation of seed vigor has evolved as available tests have been improved and adapted to different species and resulted in reproducible results (Marcos-Filho, 1999). When field conditions are favorable during the sowing season, there are generally no serious concerns about the accuracy of the germination results obtained in the laboratory; however, when seeds are exposed to less favorable environmental conditions, seedling emergence may significantly differ from the germination determined in the laboratory.

Temperature is one of the most significant environmental conditions affecting germination (Mayer and Poljakoff-Mayber, 1989). In many species, temperature influences percentage and speed of seed germination even with ideal water availability (Heydecker, 1977; Bewley and Black, 1994), since temperature influencesthe rate of water absorption by seeds (Shull, 1920) as well as the chemical reactions regulating metabolism during the germination process (Carvalho and Nakagawa, 2000). The optimal temperature for most species is $20-30{ }^{\circ} \mathrm{C}$ with a maximum of $35-40{ }^{\circ} \mathrm{C}$ (Marcos-Filho, 1986). In general, temperature accelerates germination, while lowerthan optimal temperatures primarily affect the speed of germination (Marcos-Filho, 1986; Carvalho e Nakagawa, 2000).

Reduced germination speed and an increased time interval between the germination of the first and last seeds within a lot are significant symptoms of reductions in physiological potential causing non-uniform seedling emergence (Eira and Marcos-Filho, 1990). According to Globirson (1981), uniform seedling emergence in the field is very important for vegetable crops due to the high cost of seeds and labor, as well as the high financial and technological investments.

Vigor positively influenced seed performance at different temperatures in lettuce (Nascimento and Pereira, 2007), tomatoes (Oliveira et al., 2001) and carrots (Carneiro and Guedes, 1992); these studies also emphasized that genotype might affect the results.

The objective in the present study was to determine the relationship between the physiological potential of bell pepper seeds determined in the laboratory and germination at different temperatures and seedling emergence.

\section{MATERIAL AND METHODS}

This research was carried out at the Seed Analysis Laboratory of the Department of Crop Science, "Luiz de Queiroz" College of Agriculture/University of São Paulo (USP/ESALQ) in Piracicaba, SP, Brazil.

Five lots each of two bell pepper hybrids (Reinger and Sentinel) produced by Syngenta Seeds Ltda. were used. Since the lots possessed high germination and uniform performance, three seed lots were artificially aged at $41{ }^{\circ} \mathrm{C}$ for 24,48 and 72 hours, respectively, to induce differences in vigor. Seeds were then allowed to dry on paper towels in a chamber $\left(20{ }^{\circ} \mathrm{C}\right.$ and $60 \%$ relative air humidity) until moisture content was close to the original values. Each lot was then carefully homogenized, placed in airtight aluminum packages and stored in a chamber $\left(20{ }^{\circ} \mathrm{C}\right.$ and $60 \%$ relative air humidity) for the wole experimental period. After removing test samples to perform each test, packages were resealed and stored again. Two evaluations were made (March and August, 2008) and included the following tests:

Germination: four replications of 50 seeds per lot were distributed on two sheets of blotting paper that had been moistened with water 2.5 times (approximately $13 \mathrm{~mL}$ ) the weight of the dry substrate and placed in transparent plastic boxes $(11.5 \times 11.5 \times 3.5 \mathrm{~cm})$ under alternating temperature $\left(20-30{ }^{\circ} \mathrm{C}\right)$ with light during the higher temperature period. The percent of normal seedlings was calculated 14 days after sowing (Brasil, 1992).

Saturated salt accelerated aging: seeds $(2.0 \mathrm{~g}$ per lot $)$ were placed on a wire mesh in a single layer in plastic boxes $(11.5 \times 11.5 \times 3.5 \mathrm{~cm})$ as individual compartments (mini chambers). Forty $\mathrm{mL}$ of saturated salt solution were added to each box, providing an environment with $76 \%$ relative 
humidity, for 48 hours at $41{ }^{\circ} \mathrm{C}$ (Panobianco and Marcos Filho, 1998).

Seedling emergence in greenhouse: four replications of 50 seeds were distributed on polystyrene trays with 200 cells containing a commercial substrate (Plantimax - Hortaliças). Trays were kept in a greenhouse at room temperature and irrigated daily. Percent seedling emergence was determined 14 days after sowing by counting plants with shoot lengths of at least $1 \mathrm{~cm}$. The number of emerged seedlings was recorded daily to determine the speed of emergence index according to Maguire (1962).

Moisture content: determined before setting up each test and after accelerated aging in an oven at 105 ${ }^{\circ} \mathrm{C} \pm 3{ }^{\circ} \mathrm{C}$, for $24 \mathrm{~h}$ (Brasil, 1992) in two samples with $2.0 \mathrm{~g}$ seeds per lot. Results were expressed as a mean percentage (fresh weight) per lot.

Germination at different temperatures: three replications of 25 seeds per lot were distributed on three sheets of blotting paper moistened with water 2.5 times the weight of the dry substrate in Petri dishes sealed with plastic wrap. Samples were kept on a thermogradient table at five temperatures $\left(15^{\circ} \mathrm{C}, 18{ }^{\circ} \mathrm{C}, 2{ }^{\circ} \mathrm{C}, 25^{\circ} \mathrm{C}\right.$ and $\left.30^{\circ} \mathrm{C}\right)$ with a daily eight-hour photoperiod. Normal and abnormal seedlings and non-germinated seeds were recorded daily until 21 days after test initiation. The characterization of normal seedlings and the results were done according to the Rules for Testing Seed (Brasil, 1992). Speed of germination was determined based on daily counts of the number of normal seedlings according to Maguire (1962).

Tetrazolium: seeds were pre-conditioned in four replications of $1 \mathrm{~g}$ seeds each per lot, distributed between two sheets of blotter paper moistened with water 2.5 times the weight of the dry paper and placed in a plastic box $(11.5 \times 11.5 \times 3.5 \mathrm{~cm})$. Samples were then placed in germinators regulated at $45{ }^{\circ} \mathrm{C}$. Each replication was weighed at 60-minute intervals for five hours to monitor seed moisture content (fresh weight) at the end of each period in order to identify the best period to produce a clear seed coloration. After pre-conditioning, four replicates of 25 seeds each per lot were cut lengthwise, dividing the seeds into two halves without separating them, and immersed in $15 \mathrm{~mL} 0.075 \%$ tetrazolium solution at 45 ${ }^{\circ} \mathrm{C}$ for 1,2 and 3 hours. The seeds were then washed and immersed in water for approximately 10 minutes, after which they were evaluated individually by examining one of the halves under a stereoscopic microscope. Viable and non-viable seeds were photographed with a digital camera (Nikon model D1) and the images transferred to the computer using Nikoncapture Powerful Imaging Software for the Nikon D1 and adjusted using Photoshop 6. To evaluate vigor and viability, seeds were classified according to Santos et al., (2007) as follows: 1) viable and vigorous: pink coloration throughout the embryo and endosperm, with turgid, firm tissue and no apparent lesions (Figure 1); 2) viable and non-vigorous: turgid, firm tissues with no color in less than $50 \%$ of the cotyledons or endosperm; apex of the radicle-hypocotyl axis may be colorless (Figure $2-\mathrm{A}, \mathrm{B}, \mathrm{C}$ ); 3 ) non-viable: more than $50 \%$ of cotyledon and/or endosperm areas unstained or with no color at the radicle axis with flaccid, white or yellowish tissues; areas of the endosperm and/ or embryo may also be totally lacking color (Figure 3). Results were expressed as percentage of viable vigorous and non-vigorous seeds.

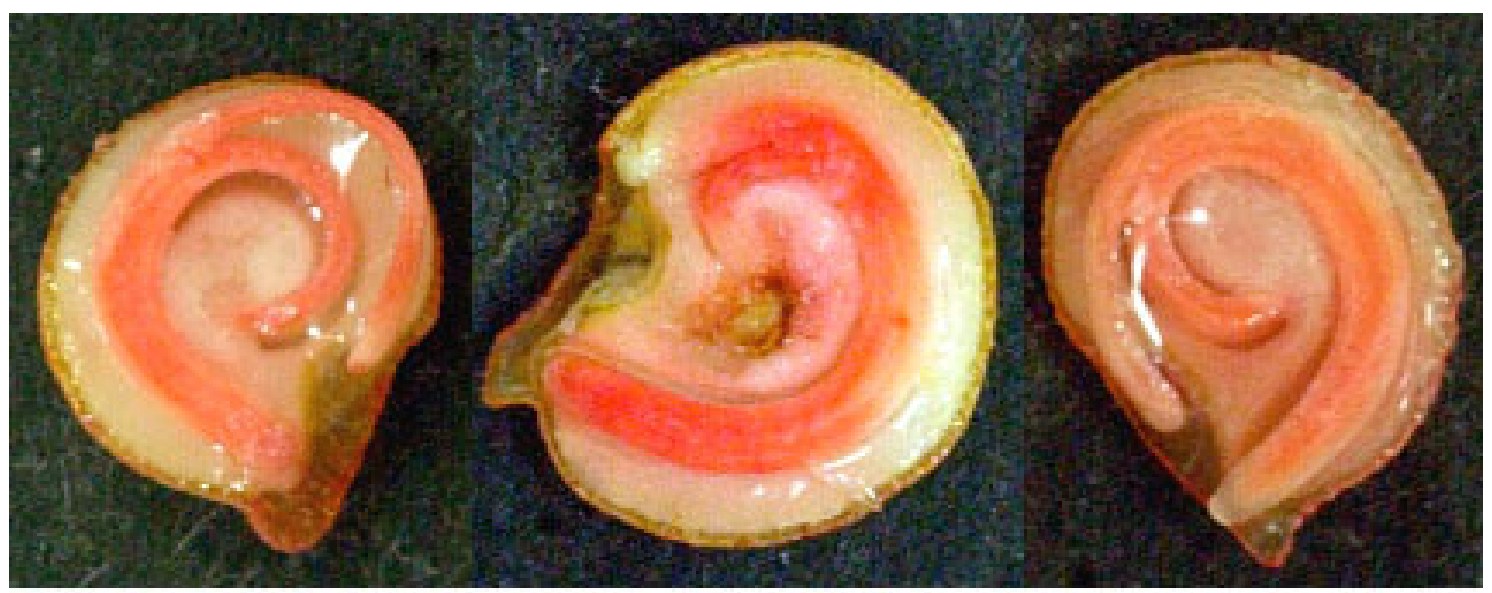

FIGURE 1. Viable, vigorous bell pepper seeds, preconditioned for $3 \mathrm{~h}$ at $45{ }^{\circ} \mathrm{C}$ and stained for $2 \mathrm{~h}$ in a $0.075 \%$ tetrazolium solution at $45^{\circ} \mathrm{C}$. 


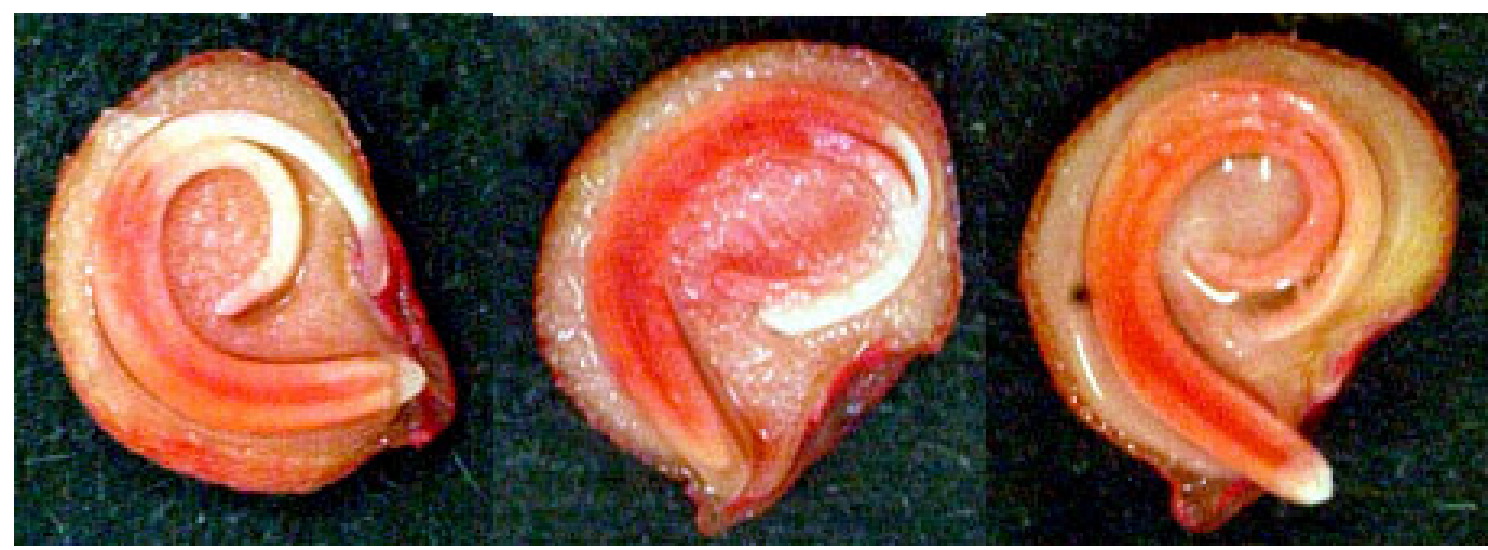

FIGURE 2. Viable, non-vigorous bell pepper seeds, preconditioned for $3 \mathrm{~h}$ at $45^{\circ} \mathrm{C}$ and stained for $2 \mathrm{~h}$ in a $0.075 \%$ tetrazolium solution at $45{ }^{\circ} \mathrm{C}$. A: cotyledons and radicle apex colorless; B: one of the cotyledons colorless; $\mathrm{C}$ : radicle apex colorless.

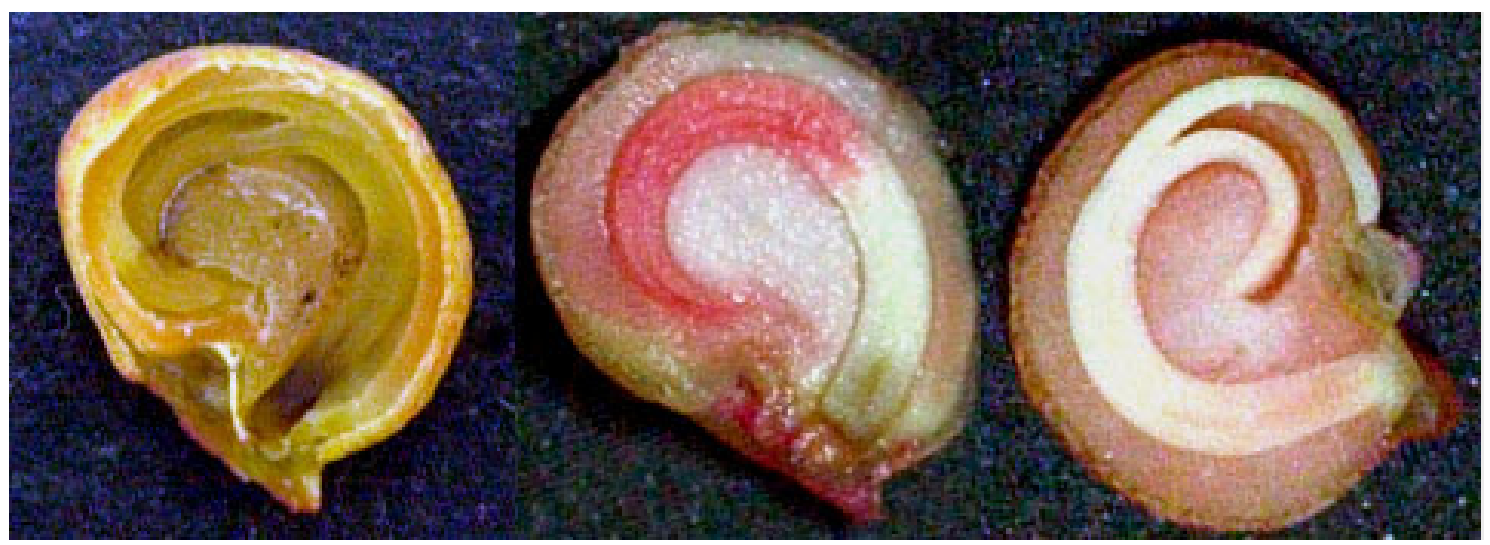

FIGURE 3. Non-viable bell pepper seeds, preconditioned for $3 \mathrm{~h}$ at $45^{\circ} \mathrm{C}$ and stained for $2 \mathrm{~h}$ in a $0.075 \%$ tetrazolium solution at $45^{\circ} \mathrm{C}$.

Statistical Procedure: Data were evaluated using SANEST software (Zonta and Machado, 1984). Data for germination, accelerated aging, germination at different temperatures, seedling emergence and tetrazolium were transformed to arc $\sin \sqrt{ } \mathrm{x} / 100$; speed of germination under different temperatures and speed of seedling emergence data were not transformed. Means were compared using the Tukey test $(\mathrm{p} \leq 0.05$ error level).

\section{RESULTS AND DISCUSSION}

The two experimental periods (March and August, 2008) showed the same results; consequently, only data from the first period will be presented and discussed. Germination was not significantly different between
'Reinger' ( $81 \%$ to $88 \%$ ) and 'Sentinel' ( $83 \%$ to $93 \%$ ) hybrid seed lots (Table 1); these values were higher than the minimum standards $(80 \%)$ established for the commercialization of bell pepper seeds.

In contrast to the germination test, accelerated aging was able to differentiate 'Reinger' seed lots (Table 1). Lots 1 and 5 showed the best and worst performances respectively. Regarding the percent and speed of seedling emergence, lots 1 and 2 showed similar perfomance but were better than the others. For 'Sentinel' seed lots (Table 1), accelerated aging was closely related to the percentage of seedling emergence, with lot 7 possessing a superior and lot 9 an inferior seed vigor. The speed of seedling emergence index indicated 'Sentinel' lots 6 and 7 to be superior. 
TABLE 1. Mean values of initial moisture content (ISMC), moisture content after accelerated aging (SMC after AA), germination (G), saturated salt accelerated aging (SSAA), percent of seedling emergence (SE), speed of emergence index (SEI), tetrazolium viability (1-2) and tetrazolium vigor (1) tests performed with 'Reinger' and 'Sentinel' bell pepper seed lots.

\begin{tabular}{|c|c|c|c|c|c|c|c|c|c|}
\hline Hybrids & Lots & ISMC & $\begin{array}{c}\text { SMC } \\
\text { after AA }\end{array}$ & $\mathrm{G}$ & SSAA & SE & SEI & $\begin{array}{c}\text { TZ Viab } \\
(1-2)\end{array}$ & $\begin{array}{c}\text { TZ Vigor } \\
\text { (1) }\end{array}$ \\
\hline \multicolumn{10}{|c|}{ 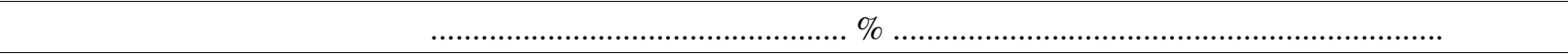 } \\
\hline \multirow{5}{*}{ Reinger } & 1 & 4.9 & 10.6 & $83 \mathrm{~A}$ & $84 \mathrm{~A}$ & $91 \mathrm{~A}$ & $4.2 \mathrm{~A}$ & $93 \mathrm{~A}$ & $84 \mathrm{~A}$ \\
\hline & 2 & 5.5 & 10.7 & $82 \mathrm{~A}$ & $76 \mathrm{AB}$ & $91 \mathrm{~A}$ & $4.0 \mathrm{~A}$ & $94 \mathrm{~A}$ & $79 \mathrm{AB}$ \\
\hline & 3 & 5.6 & 10.3 & $88 \mathrm{~A}$ & $78 \mathrm{AB}$ & $56 \mathrm{~B}$ & $2.0 \mathrm{~B}$ & $89 \mathrm{~A}$ & $69 \mathrm{~B}$ \\
\hline & 4 & 5.9 & 10.3 & $81 \mathrm{~A}$ & $75 \mathrm{AB}$ & $68 \mathrm{~B}$ & $2.6 \mathrm{~B}$ & $88 \mathrm{~A}$ & $66 \mathrm{~B}$ \\
\hline & 5 & 5.9 & 10.7 & $83 \mathrm{~A}$ & $65 \mathrm{~B}$ & $69 \mathrm{~B}$ & $2.6 \mathrm{~B}$ & $88 \mathrm{~A}$ & $69 B$ \\
\hline C.V. (\%) & & - & - & 5.2 & 6.7 & 11.4 & 13.3 & 7.9 & 7.6 \\
\hline \multirow{5}{*}{ Sentinel } & 6 & 5.4 & 10.5 & $83 \mathrm{~A}$ & $57 \mathrm{CD}$ & $92 \mathrm{AB}$ & $4.2 \mathrm{~A}$ & $90 \mathrm{~A}$ & $54 \mathrm{AB}$ \\
\hline & 7 & 6.2 & 10.2 & $93 \mathrm{~A}$ & $94 \mathrm{~A}$ & $97 \mathrm{~A}$ & $4.4 \mathrm{~A}$ & $90 \mathrm{~A}$ & $67 \mathrm{~A}$ \\
\hline & 8 & 6.7 & 10 & $90 \mathrm{~A}$ & $73 B$ & $93 \mathrm{AB}$ & $3.5 \mathrm{~B}$ & $92 \mathrm{~A}$ & $65 \mathrm{~A}$ \\
\hline & 9 & 6.4 & 10.5 & $85 \mathrm{~A}$ & $53 \mathrm{D}$ & $60 \mathrm{C}$ & $2.3 \mathrm{C}$ & $80 \mathrm{~A}$ & $46 \mathrm{~B}$ \\
\hline & 10 & 6.9 & 10.3 & $86 \mathrm{~A}$ & $65 \mathrm{BC}$ & $81 \mathrm{~B}$ & $3.4 \mathrm{~B}$ & $87 \mathrm{~A}$ & $63 \mathrm{~A}$ \\
\hline C.V. (\%) & & - & - & 6.9 & 4.6 & 7.5 & 5.9 & 8.1 & 7.5 \\
\hline
\end{tabular}

Means followed by the same letter within a column are not significantly different by Tukey's test $(\mathrm{p} \leq 0.05)$.

In general, the vigor tests consistently indicated wide differences in physiological seed potential, identifying the most and least vigorous seeds. Some lots of both hybrids showed intermediate behavior with differing levels of quality depending on the test used. Identifying lots of intermediate vigor is not simple, since variations in seed performance depend on the test, or rather on the characteristic evaluated, especially when dealing with lots possessing germination above than the minimum established for commercialization (Kulik and Yaklich, 1982; Marcos-Filho et al., 1984).

Mean viability of the ten bell pepper seed lots evaluated by the tetrazolium test indicated that preconditioning for three hours at $45^{\circ} \mathrm{C}$, and contact with the tetrazolium solution for two hours at $45{ }^{\circ} \mathrm{C}$, did not show any differences between the lots, confirming the germination results (Table 1). However, the methodology proposed in the present study was comparable to that established by the Rules for Testing Seeds (Brasil, 1992) to evaluate germination in Capsicum spp. seeds, but with the advantage of reducing the time needed for results.
Despite not including a more in-depth study of the general procedure for conducting the tetrazolium test, results indicated a possibility of reducing the concentration of the tetrazolium solution and the preconditioning period, since the Rules for Testing Seeds recommend concentrations of $0.5 \%$ or $1 \%$ and a $24 \mathrm{~h}$ staining period in the tetrazolium solution. After three hour pre-hydration at $45{ }^{\circ} \mathrm{C}$, seeds reached a moisture content close to $33 \%$ and facilitated a precise cutting to expose the internal seed parts. In contrast, after the $1 \mathrm{~h}$ and $3 \mathrm{~h}$ pre-conditioning periods, seed moisture content was $26 \%$ and $29 \%$ respectively; at those moisture content levels, seed cutting was imprecise and seed coloration was not uniform and, thus, preliminary results were not as consistent as desired. For this reason, these pre-conditioning periods were not studied here. Seed immersion in tetrazolium solution for two hours resulted in the uniform coloration of vital seed parts, making tissues easier to evaluate. As a consequence, the selection of the most adequate tetrazolium testing procedure in the present research was based on the efficiency of differentiating viable and non-viable tissues and the ability to identify lots 
with distinct physiological potentials.

A comparison of the germination rate and tetrazolium viability (TZ 1-2) of the 'Reinger' hybrid illustrates the consistency of the information supplied by these two tests, since neither indicates significant differences between the lots evaluated, which also occurred for the Sentinel hybrid (Table 1).

Accelerated aging, seedling emergence and TZ-vigor (Table 1) confirmed different physiological potentials of the seed lots evaluated. For the Reinger hybrid, there was a relationship between TZ-vigor and the percentage and speed of seedling emergence, with lots 1 and 2 identified as the most vigorous, and lots 3,4 , and 5 as inferior. For the Sentinel hybrid, the TZ-vigor test identified lots 7,8 and 10 as superior and lot 9 as having the worst performance.

Germination tests conducted in a thermogradient table showed that Reinger hybrid seed lots did not vary significantly, regardless of the temperature used (Table 2). An evaluation of the lot performance at each temperature showed a decrease in the percentage of seeds germinated at $18{ }^{\circ} \mathrm{C}$. No normal seedlings were produced at $15{ }^{\circ} \mathrm{C}$. Thus, the percentage of germination printed on the label of a determined seed lot may differ markedly from seedling emergence in the field if the soil temperature at the time of sowing is not completely favorable (Nascimento, 2000). This fact occurs because the temperature used to conduct bell pepper seed germination tests in the laboratory, in accordance with the Rules for Seeds Testing (Brasil, 1992), is 20-30 ${ }^{\circ} \mathrm{C}$. When bell peppers are not cultivated in a greenhouse, temperature deviations may occur, adversely affecting seedling emergence.

Temperature clearly influenced germination of the 'Sentinel' seed lots (Table 2). The highest percentages were observed in seeds exposed to $30{ }^{\circ} \mathrm{C}, 25{ }^{\circ} \mathrm{C}$ and $21{ }^{\circ} \mathrm{C}$. Only primary root protrusion occurred in most seeds from all lots of both hybrids germinated at $15{ }^{\circ} \mathrm{C}$, with no subsequent seedling development. Lots 7, 8 and 10 showed the best performances at all temperatures.

TABLE 2. Mean germination values of 'Reinger' and 'Sentinel' pepper seed lots at five different temperatures on the $21^{\text {st }}$ day of counting.

\begin{tabular}{|c|c|c|c|c|c|c|}
\hline \multirow{2}{*}{ Hybrids } & \multirow{2}{*}{ Lots } & \multicolumn{5}{|c|}{ Temperature $\left({ }^{\circ} \mathrm{C}\right)$} \\
\hline & & 30 & 25 & 21 & 18 & 15 \\
\hline & & \multicolumn{5}{|c|}{ 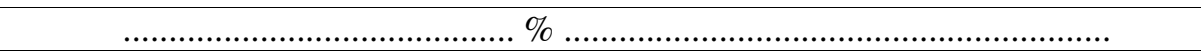 } \\
\hline \multirow{5}{*}{ Reinger } & 1 & 98Aa & $92 \mathrm{Aa}$ & $91 \mathrm{Aa}$ & $64 \mathrm{Ab}$ & 00Ac \\
\hline & 2 & $85 \mathrm{Aa}$ & 94Aa & $87 \mathrm{Aa}$ & $71 \mathrm{Ab}$ & 00Ac \\
\hline & 3 & 88Aa & 92Aa & 95Aa & $67 \mathrm{Ab}$ & 00Ac \\
\hline & 4 & $95 \mathrm{Aa}$ & $91 \mathrm{Aa}$ & $95 \mathrm{Aa}$ & $70 \mathrm{Ab}$ & $00 \mathrm{Ac}$ \\
\hline & 5 & $93 \mathrm{Aa}$ & $96 \mathrm{Aa}$ & $93 \mathrm{Aa}$ & $62 \mathrm{Ab}$ & $00 \mathrm{Ac}$ \\
\hline $\mathrm{CV}(\%)$ & & \multicolumn{5}{|c|}{10.4} \\
\hline \multirow{5}{*}{ Sentinel } & 6 & $73 \mathrm{Ba}$ & 61Bab & $48 \mathrm{Cb}$ & $18 \mathrm{Cc}$ & 00Ad \\
\hline & 7 & 98Aa & $100 \mathrm{Aa}$ & $95 \mathrm{Aa}$ & $76 \mathrm{Ab}$ & $00 \mathrm{Ac}$ \\
\hline & 8 & 99Aa & 98Aa & $80 \mathrm{ABb}$ & $64 \mathrm{ABb}$ & $00 \mathrm{Ac}$ \\
\hline & 9 & $68 \mathrm{Ba}$ & $63 \mathrm{Bb}$ & $67 \mathrm{BCa}$ & $18 \mathrm{Cb}$ & 00Ac \\
\hline & 10 & $98 \mathrm{Aa}$ & $98 \mathrm{Aa}$ & $98 \mathrm{Aa}$ & $48 \mathrm{Bb}$ & $00 \mathrm{Ac}$ \\
\hline $\mathrm{CV}(\%)$ & & \multicolumn{5}{|c|}{12.6} \\
\hline
\end{tabular}

Means followed by the same upper case letter within a column and lower case letter within a row are not significantly different by Tukey's test ( $\mathrm{p} \leq$ $0.05)$.

Lower germination of lots 6 and 9 was probably determined by lower seed vigor, detected by the accelerated aging and tetrazolium tests (Table 1). As emphasized by Marcos-Filho (1986) and Carvalho and Nakagawa (2000), vigorous seeds usually exhibit higher germination potential under a wide range of temperatures, so that seeds from lots 6 and 9 were more affected by the temperature decrease. On the other hand, seed lots 7, 8 and 10 showed reduced germination when seeds were exposed to $18{ }^{\circ} \mathrm{C}$ and $21^{\circ} \mathrm{C}$, which indicates that these temperatures are also unfavorable for seedling development in bell peppers.

Temperature also affected the mean values of the germination speed index of Ranger seed lots (Table 3). Seeds germinated faster when exposed to $30^{\circ} \mathrm{C}$ and 
$25^{\circ} \mathrm{C}$, with lot 1 having the highest and lot 5 the slowest germination values. Despite germination at $21{ }^{\circ} \mathrm{C}$ being relatively high (Table 2), the speed of germination index (Table 3) indicates that a $9^{\circ} \mathrm{C}$ temperature decrease (from
$30{ }^{\circ} \mathrm{C}$ to $21^{\circ} \mathrm{C}$ ) caused germination speed to decrease by approximately $50 \%$, indicating that this parameter is more sensitive for evaluating the potential performance of bell pepper seeds than the germination percentage.

TABLE 3. Mean values of speed of germination index (SGI) of 'Reinger' and 'Sentinel' bell pepper seed lots at five different temperatures until the $21^{\text {st }}$ day of counting.

\begin{tabular}{lcllclc}
\hline \multirow{2}{*}{ Hybrids } & Lots & \multicolumn{5}{c}{ Temperatures $\left({ }^{\circ} \mathrm{C}\right)$} \\
\cline { 2 - 6 } & 1 & 30 & 25 & 21 & 18 & 15 \\
\hline \multirow{3}{*}{ Reinger } & 2 & $2.4 \mathrm{Aa}$ & $2.1 \mathrm{Ab}$ & $1.4 \mathrm{Ac}$ & $0.8 \mathrm{Ad}$ & $0.0 \mathrm{Ae}$ \\
& 3 & $2.2 \mathrm{ABa}$ & $1.9 \mathrm{ABb}$ & $1.5 \mathrm{Ac}$ & $1.0 \mathrm{Ad}$ & $0.0 \mathrm{Ae}$ \\
& 4 & $2.1 \mathrm{Ba}$ & $1.9 \mathrm{Ba}$ & $1.4 \mathrm{Ab}$ & $0.9 \mathrm{Ac}$ & $0.0 \mathrm{Ad}$ \\
& 5 & $2.2 \mathrm{ABa}$ & $1.9 \mathrm{ABb}$ & $1.5 \mathrm{Ac}$ & $0.9 \mathrm{Ad}$ & $0.0 \mathrm{Ae}$ \\
$\mathrm{nyV}(\%)$ & $1.5 \mathrm{Ca}$ & $1.1 \mathrm{Cb}$ & $0.8 \mathrm{Bc}$ & $0.8 \mathrm{Ad}$ & $0.0 \mathrm{Ad}$ \\
\hline & & & 8.2 & & $0.8 \mathrm{ABb}$ & $0.0 \mathrm{Ac}$ \\
& 6 & $1.9 \mathrm{Ba}$ & $1.7 \mathrm{Ba}$ & $1.00 \mathrm{Cb}$ & $1.1 \mathrm{Ad}$ & $0.0 \mathrm{Ae}$ \\
Sentinel & 7 & $2.4 \mathrm{Aa}$ & $2.0 \mathrm{Aa}$ & $1.5 \mathrm{ABc}$ & $0.6 \mathrm{BCc}$ & $0.0 \mathrm{Ad}$ \\
& 8 & $2.2 \mathrm{ABa}$ & $2.0 \mathrm{ABa}$ & $1.2 \mathrm{BCb}$ & $0.3 \mathrm{Cb}$ & $0.0 \mathrm{Ab}$ \\
& 9 & $1.1 \mathrm{Ca}$ & $1.1 \mathrm{Ca}$ & $0.9 \mathrm{Ca}$ & $0.6 \mathrm{BCc}$ & $0.0 \mathrm{Ad}$ \\
\hline $\mathrm{CV}(\%)$ & 10 & $2.1 \mathrm{ABa}$ & $2.0 \mathrm{Aa}$ & $1.7 \mathrm{Ab}$ & & \\
\hline
\end{tabular}

Means followed by the same upper case letter within a column and lower case letter within a row are not significantly different by Tukey’s test ( $\mathrm{p} \leq 0.05$ ).

When germination was performed at $18{ }^{\circ} \mathrm{C}$, speed of germination of all 'Reinger' lots was similar. However, in this case, it was impossible to differentiate the seed vigor of the lots evaluated, indicating that the temperature should be carefully selected to obtain the desired information.

'Sentinel' lots also showed a higher speed of germination index at $30{ }^{\circ} \mathrm{C}$ and $25{ }^{\circ} \mathrm{C}$. At these two temperatures, lot 7 possessed the highest speed of germination index but did not differ significantly from lots 8 and 10. Once again, lot 9 showed the worst performance. These results are comparable to those of Bierhuizen et al., (1978).

In the present study, bell pepper seeds germinated faster at $30{ }^{\circ} \mathrm{C}$ and $25^{\circ} \mathrm{C}$. Decreases in temperature from $21{ }^{\circ} \mathrm{C}$ and lower began to limit growth, with reduced speed of germination.

In general, until the $14^{\text {th }}$ day of evaluations on a thermogradient table, most seeds produced normal seedlings at $30{ }^{\circ} \mathrm{C}$ and $25{ }^{\circ} \mathrm{C}$. However, under these conditions, seedling growth from the Reinger hybrid seeds was not the same for all lots. For example, lots 4 and 5 had relatively low vigor with smaller seedlings having less developed roots and practically no secondary roots. This demonstrates that the germination of seeds exposed to sub-optimal temperatures produces seedlings that are probably more sensitive to stress, which may compromise the stand and plant performance.

Inconsistent performance is undesirable for a grower, especially when using relatively expensive hybrid seeds (Nascimento, 2000). Therefore, germination evaluation on a thermogradient table may greatly contribute to estimating the performance of bell pepper seed lots exposed to adverse temperatures.

The present study has produced relevant information concerning procedures to determine the physiological potential of bell pepper seeds, identifying tests recommended for inclusion in quality control programs 
and an improvement in the tetrazolium test protocol.

At the same time, the germination of bell pepper seed lots varied at different temperatures, which has already been described in the literature. However, the association of this behavior with the level of seed lot vigor and the possibility of evaluating germination on a thermogradient table, thus obtaining information comparable to those of vigor tests, represents an important advance in knowledge.

\section{CONCLUSIONS}

Data analysis and interpretation of the results of the present study have led to the following conclusions:

Saturated salt accelerated aging and tetrazolium (preconditioning at $45^{\circ} \mathrm{C} / 3 \mathrm{~h}$ and staining at $45^{\circ} \mathrm{C} / 2 \mathrm{~h}$ ) tests are efficient for evaluating the physiological potential of bell pepper seeds;

Vigorous lots present consistent germination when exposed to temperature variations.

\section{ACKNOWLEDGEMENTS}

To CNPq and FAPESP respectively for scholarships and financial support and to Syngenta Seeds Ltda for supplying the seeds.

\section{REFERENCES}

BEWLEY, J.D.; BLACK, M. Seeds: physiology of development and germination. $2^{\text {nd }}$ ed. New York: Plenum Press, 1994. 445p.

BIERHUIZEN, J.F.; WAGENVOORT, W.A.; NILWIK, $\mathrm{H}$. Analysis of the relationship between temperature and germination of sweet pepper. Acta Horticulturae, n.83, p.195-199, 1978.

BRASIL. Ministério da Agricultura e Reforma Agrária. Secretaria Nacional de Defesa Agropecuária. Departamento Nacional de Produção Vegetal. Coordenação de Laboratório Vegetal. Regras para Análise de Sementes. Brasília, DF, 1992. 365p.

CARNEIRO, J.W.P.; GUEDES, T.A. Influência da temperatura no desempenho germinativo de sementes de cenoura (Daucus carota L.), avaliada pela função de distribuição de Weibull. Revista Brasileira de Sementes, v.14, n.2, p.207-213, 1992.

CARVALHO, N.M.; NAKAGAWA, J. Sementes: ciência, tecnologia e produção. 4.ed. Jaboticabal: FUNEP, 2000. $588 \mathrm{p}$.

EIRA, M.T.S.; MARCOS-FILHO, J. Condicionamento osmótico de sementes de alface. I. Efeitos sobre a germinação. Revista Brasileira de Sementes, v.12, n.1, p.9-27, 1990.

GLOBIRSON, D. The quality of lettuce seed harvested at different times after anthesis. Seed Sciencie and Technology, v.9, p.861-866, 1981.

HAMPTON, J.G.; COOLBEAR, P. Potential versus actual seed performance: can vigour testing provide an answer? Seed Science and Technology, v.18, n.2, p.215-228, 1990.

HEYDECKER, W. Stress and seed germination: an agronomic view. In: KHAN, W. The physiology and biochemistry of seed dormancy and germination. Amsterdam. Elservier, 1977. p.237-282.

KULIK, M.M.; YAKLICH, R.W. Evaluation for vigor tests in soybean seeds relationship of accelerated aging, cold, sand bench and speed of germination tests to field performance. Crop Science, v.22, n.4, p.776-770, 1982.

MAGUIRE, J.D. Speed of germination-aid in selection and evaluation for seedling emergence and vigor. Crop Science, v.2, n.1, p.176-177, 1962.

MARCOS-FILHO, J. Germinação de sementes. In: CÍCERO, S.M.; MARCOS-FILHO, J.; SILVA, W.S. Atualização em produção de sementes. Campinas: Fundação Cargill, 1986. p.11-39.

MARCOS-FILHO, J. Testes de vigor: importância e utilização. In: KRZYZANOWSKI, F.C.; VIEIRA, R.D.; FRANÇA NETO, J.B. (Ed.). Vigor de sementes: conceitos e testes. Londrina: ABRATES, 1999. cap. 1, p.1-21.

MARCOS-FILHO, J.; PESCARIN, H.M.C.; KOMATSU, Y.H.; DEMÉTRIO, C.G.B.; FANCELLI, A.L. Testes para a avaliação do vigor de sementes de soja e suas relações com a emergência de plântulas no campo. Pesquisa Agropecuária Brasileira, v.19, n.5, p.605-613, 1984.

MAYER, A.M.; POLJAKOFF-MAYBER. The germination of seeds. Oxford: Pergamon Press, 1989. 270p.

NASCIMENTO, W.M. Temperatura x germinação. Seed News, v.4, n.4, p.44-45, jul./ago. 2000.

NASCIMENTO, W.M.; PEREIRA, R.S. Testes para avaliação do potencial fisiológico de sementes de alface e sua relação com a germinação sob temperaturas adversas. 
Revista Brasileira de Sementes, v.29, n.3, p.175-179, 2007.

OLIVEIRA, A.P.; BRUNO, R.L.A.; ALVES, E.U. Influência do substrato e da temperatura na germinação de sementes peletizadas de tomate. Revista Brasileira de Sementes, v.23, n.2, p.72-77, 2001.

PANOBIANCO, M.; MARCOS-FILHO, J. Comparação entre métodos para avaliação da qualidade fisiológica de sementes de pimentão. Revista Brasileira de Sementes, v.20, n.2, p.68-72, 1998.
SANTOS, M.A.O.; NOVEMBRE, A.D.L.C.; MARCOSFILHO, J. Tetrazolium test to assess viability and vigour of tomato seeds. Seed Science and Technology, v.35, n.1, p.213-223, 2007.

SHULL, C.A. Temperature and rate moisture intake in seeds. Botanical Gazette, v.69, n.5, p.361-390, 1920.

ZONTA, E.P.; MACHADO, A.A. SANEST: Sistema de Análise Estatística para Microcomputadores. Pelotas: Universidade Federal de Pelotas, 1984. 